\title{
Tobacco and waterpipe use among university students in Saudi Arabia: impact of tobacco sales ban
}

Haytham Daradka, ${ }^{1}$ Omar Khabour, ${ }^{2,3}$ Karem Alzoubi, ${ }^{4}$ Rima Nakkash ${ }^{5}$ and Thomas Eissenberg ${ }^{6}$

${ }^{1}$ Department of Biology, Taibah University, Medina, Saudi Arabia (Correspondence to: H. Daradka: hmdaradka@yahoo.com). ${ }^{2}$ Department of Clinical Laboratory Sciences, Taibah University, Medina, Saudi Arabia. ${ }^{3}$ Department of Medical Laboratory Sciences, Jordan University of Science and Technology, Irbid, Jordan. ${ }^{4}$ Department of Clinical Pharmacy, Jordan University of Science and Technology, Irbid, Jordan. ${ }^{5}$ Department of Health Promotion and Community Health, American University of Beirut, Beirut, Lebanon. ${ }^{6}$ Department of Psychology, Virginia Commonwealth University, Richmond, VA, United States of America.

\begin{abstract}
Background: Waterpipe smoking is a method of tobacco consumption that continues to spread globally. In 2002, a ban of tobacco sales was adopted in the Saudi Arabian cites of Mecca and Medina.

Aims: This study aimed to examine prevalence of waterpipe and cigarette smoking among students of Taibah University, the biggest in Medina, where the tobacco sales ban has been implemented.

Methods: A structured questionnaire was distributed between February and April 2015 to examined tobacco use among Taibah University students.

Results: The prevalence of current and ever waterpipe use was $24.2 \%$ and $36.04 \%$, respectively, compared with $31.9 \%$ and $42.7 \%$ for current and ever cigarette smoking. This prevalence is similar to that reported in other Saudi cities where tobacco sales are allowed. Multivariate analysis showed that waterpipe use was higher among senior students; those with pocket money spending of $>500$ Saudi Arabia riyal (SAR)/month; and if $>5$ individuals were living in the household. In addition, waterpipe use was lower among students with monthly household income of 5000-9000 SAR. In contrast, current cigarette smoking was more frequent in those aged $>22$ years; among male students; in those with pocket money spending of $>500 \mathrm{SAR} / \mathrm{month}$; and those who lived away from their parents.
\end{abstract}

Conclusions: Waterpipe and cigarette smoking, despite the ban on tobacco sales, is still common among Taibah University students in Medina, Saudi Arabia.

Keywords: shisha, tobacco, smoking, hookah, Taibah

Citation: Daradka H; Khabour O; Alzoubi K; Nakkash R; Eissenberg T. Tobacco and waterpipe use among university students in Saudi Arabia: impact of tobacco sales ban. East Mediterr Health J. 2019;25(2):111-118. https://doi.org/10.26719/emhj.18.021

Received: 09/05/17; accepted: 01/10/17

Copyright (c) World Health Organization (WHO) 2019. Some rights reserved. This work is available under the CC BY-NC-SA 3.0 IGO license (https:// creativecommons.org/licenses/by-nc-sa/3.o/igo).

\section{Introduction}

Globally, $\sim 6$ million deaths each year are attributed to tobacco smoking (1). In addition to cigarette smoking, waterpipe tobacco smoking has become more popular (2), particularly among high school and university students (3). This growth in popularity is due, in part, to the misperception that the waterpipe filters the smoke, rendering it less harmful than other types of tobacco smoking (4). In fact, waterpipe tobacco smoke contains carcinogens such as polycyclic aromatic hydrocarbons that cause lung tumours, toxic aldehyde compounds that cause lung inflammation, high levels of carbon monoxide that contribute to cardiovascular disease, and nicotine that causes addiction (5). Animal studies have shown that waterpipe smoke exposure leads to lung inflammation, oxidative stress, and impaired pregnancy outcomes, renal function, chromosomal structure, and cognitive and mental ability (6-11). Thus, this type of smoking has the potential to cause cancer, lung disease, cardiopulmonary disease, dependence, and other disorders $(6,12)$. For these reasons, waterpipe tobacco smoking is now seen as a public health threat requiring effective policy intervention (13).
One potential intervention is to ban tobacco sales, and this approach was adopted in the Saudi Arabian cites of Mecca and Medina in 2002 (14). This is a total ban throughout the whole city including Taibah University (where the current study was conducted), and all forms of tobacco including cigarettes, cigars, Jurak, and waterpipe tobacco (waterpipe cafés are also banned, as is the sale of paraphernalia used in waterpipe tobacco smoking). Traders who violate the ban are compelled to pay a fine between 5000 and 10000 Saudi Arabian riyal (SAR) (1 SAR = US\$ 0.37), and their stores could be closed if they are cited for a third violation (15). Tobacco consumption is common in Saudi Arabia, where studies indicate that, among high-school children, the prevalence of all types of tobacco smoking was $30.3 \%$ in boys and $8.5 \%$ in girls, and waterpipe smoking represented $53.9 \%$ (both genders) of current tobacco users (16). Similar prevalence was reported among college (17) and medical and dental (1820) students.

The purpose of this study was to examine the prevalence and demographic and environmental factors associated with cigarette and waterpipe tobacco smoking among students of Taibah University, the biggest 
university in Medina. Taibah University is a government university in Saudi Arabia that has > 69000 students and offers both undergraduate and graduate programmes in most fields including basic sciences, medical sciences, engineering and humanities. As of 2014, the city of Medina had a population of $\sim 1.5$ million (21). The size of the city is $\sim 589 \mathrm{~km} 2$ and it is located in Western Saudi Arabia.

\section{Methods}

\section{Participants}

Students from Taibah University, Medina, Saudi Arabia were recruited to participate in the study. To be eligible to participate, subjects had to be at least 18 years old and enrolled as students at Taibah University. The study was conducted between February and April 2015. The study procedures were approved by the Research and Ethical Committees of Taibah University.

\section{Recruitment}

Participation was voluntary and participants were selected randomly using a two-stage cluster sampling strategy as previously described (22). The main campus regions of Taibah University were identified in both the male and female branches. The regions were allocated numbers and 3 regions from each branch were randomly selected using a fish bowl drawing method. Recruitment was facilitated by gender-specific staff from each region during the working days of a given week from 10:00 to 15:00 hours. During sampling time, every fourth student to enter the selected region was invited to be part of the study. Approximately 1700 students (1200 male and 500 female) were invited to participate in the study, and 793 male $(66 \%)$ and 274 female (35\%) students completed the anonymous survey.

\section{Instrument and measures}

The survey instrument (in Arabic) was constructed based on that used previously in Jordan (23). The instrument was modified to accommodate differences in spoken Arabic between Jordan and Saudi Arabia. To make sure that the instrument was suitable for the population, it was pilot tested in the university with 50 students and was modified according to their comments.

Among the measures was cigarette and/or waterpipe smoking, for which students were asked to report if they had smoked tobacco using a waterpipe and/or cigarettes, even a puff, in the past 30 days (current users), or ever. Demographic measures such as student specialty, age, university level, sex, paternal education, monthly household income, and pocket money spent were also obtained. For student specialty, participants were asked to select from: basic sciences, medical sciences, engineering and humanities. For paternal education, we asked participants to select from: did not complete high school, completed high school, and completed college or higher degrees. For monthly household income, we asked the student to select from the followings: SAR 0-5000, 5001-9000 and $\geq 9001$. The survey also contained items asking whether participants lived in a city or village and whether or not they lived with their parents.

\section{Data analysis}

SPSS version 21 was used for statistical analysis. The $\chi 2$ test was used to determine significant differences in prevalence of cigarette and waterpipe tobacco use across sociodemographic variables. The multivariate logistic regression method was used to determine the independent association between different variables. $P<0.05$ was considered significant.

\section{Results}

Of the 1700 invited participants, 1067 returned the questionnaire $(62.8 \%)$. Of the final sample, $793(74.3 \%)$ were male (Table 1). The age range was 18-29 years with the majority between 21 and 25 years $(662,62.8 \%)$. Most of the participants were studying basic sciences (451, 46.4\%) followed by humanities (186, 19.2\%). The majority of participants lived in the city $(982,92.4 \%)$ and with their parents (951, 89.6\%), and $424(40.7 \%)$ reported monthly household income of $<5000$ SAR. Approximately half of participants $(524,49.7 \%)$ spent $>1000$ SAR per month from pocket money.

The prevalence of current and ever waterpipe use was $24.2 \%$ and $36.04 \%$, respectively, compared with $31.9 \%$ and $42.7 \%$ for current and ever cigarette smoking. In bivariate analyses (Table 1), waterpipe tobacco use was significantly associated with university level $(P<0.001)$, age $(P<0.01)$, monthly household income $(P<0.001)$, number of others living in the home $(P<0.001)$ and living away from parents $(P<0.01)$. Current cigarette smoking was significantly associated with university level and specialty $(P<0.01)$, age $(P<0.001)$, gender $(P<0.005)$, monthly household income $(P<0.001)$, pocket money spent monthly $(P<0.001)$ and living away from parents $(P<0.01)$

In multivariate analysis (Table 2), odds of waterpipe use were significantly lower among engineering students (current and ever use) and those with monthly household income of SAR 5000-9000 (current use only). Odds of current and ever waterpipe use were significantly higher among 6th year students, those with pocket money spending of SAR > 500 per month, those with $\geq 5$ individuals living at home, and those not living with their parents. However, odds of current cigarette smoking were reported to be higher in students $\geq 22$ years of age, and among male students, in those with pocket money spending $>$ SAR 500 per month and those who lived away from parents. Ever cigarette smoking was significantly higher among students aged $\geq 23$ years, and those with income of $>500$ SAR $(\mathrm{P}<0.05)$. In addition, ever cigarette smoking was significantly lower in 2nd, 4 th and 6th university year students $(P<0.05)$.

\section{Discussion}

The results of this study showed that tobacco use is common among university students in Medina, Saudi Arabia, where sale of tobacco products is banned. The number of 
Table 1 Demographic and environmental associations with waterpipe tobacco and cigarette smoking among Taibah University students

\begin{tabular}{|c|c|c|c|c|c|c|c|c|c|}
\hline \multirow[t]{3}{*}{ Participant characteristic } & \multirow[b]{3}{*}{$\mathbf{N}\left(\%^{\mathrm{a}}\right)$} & \multicolumn{4}{|c|}{ Waterpipe tobacco } & \multicolumn{4}{|c|}{ Cigarettes } \\
\hline & & \multicolumn{2}{|c|}{ Current use } & \multicolumn{2}{|c|}{ Ever use } & \multicolumn{2}{|c|}{ Current use } & \multicolumn{2}{|c|}{ Ever use } \\
\hline & & $\%$ & $P^{*}$ & $\%$ & $P^{*}$ & $\%$ & $P^{*}$ & $\%$ & $P^{*}$ \\
\hline \multicolumn{10}{|l|}{ College } \\
\hline Basic sciences & $451(46.4)$ & 25.6 & 0.252 & 33.1 & 0.167 & 29.3 & 0.062 & 37.0 & 0.011 \\
\hline Medical sciences & $164(16.9)$ & 33.1 & & 43.1 & & 40.5 & & 47.0 & \\
\hline Engineering & $170(17.5)$ & 22.0 & & 40.0 & & 33.1 & & 47.6 & \\
\hline Humanities & $186(19.2)$ & 25.0 & & 33.3 & & 29.9 & & 34.9 & \\
\hline \multicolumn{10}{|l|}{ Year } \\
\hline 1 & $114(12.0)$ & 17.4 & $<0.001$ & 24.1 & $<0.001$ & 31.0 & 0.012 & 39.5 & $<0.001$ \\
\hline 2 & $138(14.5)$ & 29.5 & & 36.8 & & 34.1 & & 41.3 & \\
\hline 3 & $223(23.5)$ & 32.0 & & 45.4 & & 37.2 & & $45 \cdot 7$ & \\
\hline 4 & $193(20.3)$ & 28.5 & & 34.9 & & 30.5 & & 36.8 & \\
\hline 5 & $223(24.6)$ & 18.1 & & 22.4 & & 25.0 & & 28.8 & \\
\hline 6 & $48(5.1)$ & $57 \cdot 9$ & & 87.2 & & 48.9 & & 72.9 & \\
\hline \multicolumn{10}{|l|}{ Age, years } \\
\hline$>21$ & $185(17.5)$ & 23.6 & 0.005 & 33.9 & 0.173 & 23.0 & 0.002 & 33.5 & 0.002 \\
\hline 22 & $163(15.5)$ & 28.7 & & $35 \cdot 5$ & & 31.9 & & 39.3 & \\
\hline 23 & $196(18.6)$ & 38.4 & & 46.8 & & 41.3 & & 48.0 & \\
\hline 24 & $175(16.6)$ & 25.7 & & 32.6 & & 37.0 & & 39.4 & \\
\hline 25 & $128(12.1)$ & 29.6 & & 38.9 & & 29.9 & & 38.3 & \\
\hline$\geq 26$ & $208(19.7)$ & 18.4 & & 34.4 & & 38.5 & & 52.4 & \\
\hline \multicolumn{10}{|l|}{ Sex } \\
\hline Male & $793(74.3)$ & 25.5 & 0.100 & 34.8 & 0.010 & 36.8 & 0.005 & 44.0 & 0.153 \\
\hline Female & $274(25.7)$ & 31.5 & & 44.7 & & 27.3 & & 39.1 & \\
\hline \multicolumn{10}{|l|}{ Paternal education } \\
\hline $\begin{array}{l}\text { Did not complete high } \\
\text { school }\end{array}$ & $238(23.2)$ & 25.7 & 0.208 & 32.4 & $<0.001$ & 36.4 & 0.197 & 45.4 & 0.001 \\
\hline Completed high school & $346(33.7)$ & 24.5 & & 30.1 & & 29.6 & & 33.5 & \\
\hline $\begin{array}{l}\text { Completed college or } \\
\text { higher }\end{array}$ & $442(43.1)$ & 30.7 & & 47.1 & & 33.9 & & 45.7 & \\
\hline \multicolumn{10}{|c|}{ Monthly household income, $S A R^{b}$} \\
\hline $0-5000$ & $424(40.7)$ & 22.3 & $<0.001$ & 26.6 & $<0.001$ & 31.5 & $<0.001$ & 36.6 & $<0.001$ \\
\hline $5001-9000$ & $374(35.9)$ & 20.0 & & 36.9 & & 28.2 & & 39.8 & \\
\hline$\geq 9001$ & $245(23.5)$ & 43.5 & & 53.0 & & 46.5 & & 56.3 & \\
\hline \multicolumn{10}{|l|}{ No. of others living at home } \\
\hline $0-4$ & $420(39.3)$ & 18.0 & $<0.001$ & 26.7 & $<0.001$ & 34.1 & 0.806 & 40.7 & 0.548 \\
\hline $5^{-6}$ & $315(29.5)$ & 32.2 & & 42.4 & & 33.2 & & 43.2 & \\
\hline$\geq 7$ & $334(31.2)$ & 33.5 & & 45.6 & & 35.6 & & 44.6 & \\
\hline \multicolumn{10}{|c|}{ Pocket money spent monthly, $S A R^{b}$} \\
\hline $0-500$ & $274(26.0)$ & 11.8 & $<0.001$ & 15.7 & $<0.001$ & 17.5 & $<0.001$ & 21.9 & $<0.001$ \\
\hline $501-1000$ & $256(24.3)$ & 26.4 & & 42.5 & & 31.5 & & 46.9 & \\
\hline $1001-2000$ & $277(26.3)$ & 37.2 & & 46.3 & & 51.8 & & 57.0 & \\
\hline$\geq 2001$ & $247(23.4)$ & 32.3 & & 43.8 & & 36.9 & & 44.1 & \\
\hline \multicolumn{10}{|l|}{ Urban dwelling } \\
\hline City & $982(92.4)$ & 26.2 & 0.185 & 35.8 & 0.027 & 33.5 & 0.175 & 41.6 & 0.116 \\
\hline Village & $81(7.6)$ & 34.6 & & 50.9 & & 41.0 & & 50.6 & \\
\hline \multicolumn{10}{|l|}{ Living arrangement } \\
\hline With parents & $951(89.6)$ & 24.2 & $<0.001$ & $33 \cdot 3$ & $<0.001$ & 32.1 & $<0.001$ & 40.1 & $<0.001$ \\
\hline Other & $110(10.4)$ & 50.7 & & 71.4 & & 50.9 & & 62.7 & \\
\hline
\end{tabular}

*Calculated using $\chi 2$ analyses comparing proportion of users in each sociodemographic category.

${ }^{a}$ Values may not add up to 100 due to rounding.

${ }^{b} S A R 7=$ US\$ 0.37 


\begin{tabular}{|c|c|c|c|c|}
\hline \multirow[t]{2}{*}{ Participant characteristic } & \multicolumn{2}{|c|}{$\begin{array}{l}\text { AOR }(95 \% \text { CI) for waterpipe tobacco } \\
\text { smoking b }\end{array}$} & \multicolumn{2}{|c|}{$\begin{array}{l}\text { AOR (95\% CI) for cigarette } \\
\text { smoking b }\end{array}$} \\
\hline & Current use & Ever use & Current use & Ever use \\
\hline \multicolumn{5}{|l|}{ College } \\
\hline Basic sciences & 1.0 (Ref) & 1.0 (Ref) & 1.0 (Ref) & 1.0 (Ref) \\
\hline Medical sciences & $0.57(0.28-1.14)$ & $0.61(0.31-1.19)$ & $1.16(0.70-1.94)$ & $0.89(0.54-1.45)$ \\
\hline Engineering & $0.39(0.19-0.81)$ & $0.40(0.20-0.80)$ & $0.63(0.37-1.09)$ & $0.66(0.40-1.09)$ \\
\hline Humanities & $0.67(0.29-1.11)$ & $0.57(0.30-1.07)$ & $0.76(0.46-1.27)$ & $0.67(0.41-1.08)$ \\
\hline \multicolumn{5}{|l|}{ Year } \\
\hline 1 & 1.0 (Ref) & 1.0 (Ref) & 1.0 (Ref) & 1.0 (Ref) \\
\hline 2 & $1.23(0.44-3.42)$ & $0.97(0.38-2.48)$ & $0.40(0.19-0.84)$ & $0.45(0.23-0.89)$ \\
\hline 3 & $1.32(0.46-3.75)$ & $1.08(0.43-2.70)$ & $0.43(0.20-0.91)$ & $0.52(0.26-1.03)$ \\
\hline 4 & $1.55(0.50-4.79)$ & $0.62(0.23-1.71)$ & $0.24(0.11-0.54)$ & $0.25(0.12-0.54)$ \\
\hline 5 & $0.71(0.23-2.25)$ & $0.44(0.16-1.21)$ & $0.25(0.11-0.58)$ & $0.24(0.11-0.54)$ \\
\hline 6 & $8.88(1.78-44.26)$ & $29.98(5.47-64.23)$ & $0.64(0.17-2.33)$ & $4.05(1.11-14.76)$ \\
\hline \multicolumn{5}{|l|}{ Age, years } \\
\hline $18-21$ & 1.0 (Ref) & 1.0 (Ref) & 1.0 (Ref) & 1.0 (Ref) \\
\hline 22 & $1.39(0.55-3.48)$ & $1.27(0.54-3.01)$ & $2.19(1.08-4.45)$ & $1.80(0.95-3.41)$ \\
\hline 23 & $1.66(0.62-4.48)$ & $2.31(0.92-5.79)$ & $3.67(1.73-7.78)$ & $3.34(1.68-6.61)$ \\
\hline 24 & $1.61(0.57-4.56)$ & $2.45(0.92-6.53)$ & $4.46(2.01-9.87)$ & $4.06(1.96-8.43)$ \\
\hline 25 & $1.56(0.53-4.61)$ & $2.73(1.00-7.50)$ & $2.93(1.26-6.82)$ & $3.09(1.42-6.72)$ \\
\hline$\geq 26$ & $0.84(0.27-2.62)$ & $1.83(0.65-5.15)$ & $1.89(0.78-4.57)$ & $3.13(1.42-6.93)$ \\
\hline \multicolumn{5}{|l|}{ Sex } \\
\hline Male & 1.0 (Ref) & 1.0 (Ref) & 1.0 (Ref) & 1.0 (Ref) \\
\hline Female & $1.09(0.54-2.19)$ & $0.88(0.45-1.70)$ & $0.38(0.22-0.67)$ & $0.75(0.50-1.13)$ \\
\hline \multicolumn{5}{|l|}{ Paternal education } \\
\hline Did not complete high school & 1.0 (Ref) & 1.0 (Ref) & 1.0 (Ref) & 1.0 (Ref) \\
\hline Completed high school & $0.95(0.48-1.86)$ & $0.75(0.40-1.44)$ & $0.98(0.60-1.61)$ & $0.66(0.41-1.05)$ \\
\hline Completed college or higher & $0.51(0.25-1.06)$ & $0.75(0.38-1.50)$ & $0.61(0.36-1.03)$ & $0.56(0.34-0.91)$ \\
\hline \multicolumn{5}{|l|}{ Monthly household income, $S A R^{c}$} \\
\hline $0-5000$ & 1.0 (Ref) & 1.0 (Ref) & 1.0 (Ref) & 1.0 (Ref) \\
\hline $5001-9000$ & $0.40(0.20-0.81)$ & $0.73(0.38-1.39)$ & $0.77(0.46-1.29)$ & $0.82(0.51-1.33)$ \\
\hline$\geq 9001$ & $1.83(0.87-3.84)$ & $1.95(0.96-3.98)$ & $2.12(1.20-3.75)$ & $2.30(1.34-3.96)$ \\
\hline \multicolumn{5}{|l|}{ No. of others living in the home } \\
\hline $0-4$ & 1.0 (Ref) & 1.0 (Ref) & 1.0 (Ref) & 1.0 (Ref) \\
\hline $5-6$ & $2.53(1.44-4.44)$ & $2.84(1.67-4.81)$ & $1.02(0.68-1.55)$ & $1.14(0.77-1.69)$ \\
\hline 7 or more & $3.49(1.98-6.14)$ & $4.46(2.62-7.59)$ & $1.27(0.84-1.92)$ & $1.38(0.94-2.04)$ \\
\hline \multicolumn{5}{|l|}{ Pocket money spent monthly, $S A R^{c}$} \\
\hline $0-500$ & 1.0 (Ref) & 1.0 (Ref) & 1.0 (Ref) & 1.0 (Ref) \\
\hline $501-1000$ & $2.44(1.10-5.40)$ & $4.76(2.27-10.02)$ & $2.08(1.17-3.70)$ & $3.29(1.93-5.61)$ \\
\hline $1001-2000$ & $10.40(4.87-22.18)$ & $9.23(4.44-19.16)$ & $5.01(2.82-8.90)$ & $4.73(2.74-8.17)$ \\
\hline$\geq 2001$ & $4.69(1.99-11.05)$ & $3.73(1.64-8.47)$ & $2.41(1.25-4.65)$ & $2.12(1.14-3.94)$ \\
\hline \multicolumn{5}{|l|}{ Urban living } \\
\hline City & 1.0 (Ref) & 1.0 (Ref) & 1.0 (Ref) & 1.0 (Ref) \\
\hline Village & $1.42(0.48-4.23)$ & $1.15(0.39-3.37)$ & $1.11(0.51-2.44)$ & $1.27(0.59-2.72)$ \\
\hline \multicolumn{5}{|l|}{ Living arrangement } \\
\hline With parents & 1.0 (Ref) & 1.0 (Ref) & 1.0 (Ref) & 1.0 (Ref) \\
\hline Other & $2.85(1.17-6.93)$ & $3.40(1.38-8.36)$ & $2.11(1.08-4.11)$ & $1.82(1.05-3.48)$ \\
\hline
\end{tabular}

Bold values are significant.

${ }^{a}$ Values may not add up to 100 due to rounding.

${ }^{b}$ Multivariable analyses controlled for all variables in the table and were adjusted for clustering of individuals within institutions. 'SAR $1=$ US\$0.37. 
current waterpipe smokers did not differ significantly relative to that of cigarette smokers. As described below, the prevalence of tobacco use among students of Taibah University is similar to that reported in other universities in the country, indicating the ineffectiveness of banning tobacco products in the city for reducing tobacco use among students.

Several reports have examined the prevalence of tobacco use in Saudi Arabia. A 2013 survey of 10735 individuals aged $\geq 15$ years ( 5482 women and 5253 men) showed that current cigarette smoking was $12.2 \%$, while daily waterpipe smoking was reported by $4.3 \%$ of the population ( $7.3 \%$ of men and $1.3 \%$ of women) (24). A study of dental students at King Saud University in Riyadh showed that the current prevalence of all forms of tobacco smoking was $27.6 \%$ in male students and $2.4 \%$ in female students (19). The study also showed that most smokers used waterpipe only (51.5\%), followed by both waterpipe and cigarettes (25\%), or cigarettes only (23.5\%). A study of female college students in the Dammam area showed that current smoking rate was $8.6 \%$, and $43.2 \%$ of smokers were waterpipe users (25). In addition, waterpipe smoking was reported to reach $37 \%$ among healthcare university students in Saudi Arabia (26) and 36\% among dental practitioners in the Medina area (27).

Among secondary school children in Riyadh, current smoking was reported by $28.6 \%$ of the students (17). Similar numbers were reported among schoolchildren at Riyadh and Al-Hassa regions of Saudi Arabia (16). A previous study in another Saudi city before the Medina city ban reported a prevalence for current tobacco smoking of $25.3 \%$ (28). In the current study, waterpipe use was $24.2 \%$ and cigarette smoking $31.9 \%$. Thus, prohibiting selling tobacco products in Medina did not lower prevalence of cigarette and waterpipe tobacco smoking compared with that in other Saudi regions, and in some cases it was even higher. Importantly, according to the law, the ban is restricted to selling tobacco products; however, no fines are imposed on individuals who smoke inside the city. An assessment done in Mecca in 2008 showed that only $75 \%$ of stores complied with the no sale ban (29), while no such evaluation was carried out in Medina. In addition waterpipe and cigarette smokers may bring their products with them and may also smuggle them in for others.

A similar ban on tobacco sales was imposed in Bhutan in 2004. Sixty-three percent of those surveyed as part of an International Tobacco Control study reported purchasing their cigarettes from Bhutan, with sales taking place in a concealed manner, a lack of proper enforcement and availability of smuggled products (30). However, in Bhutan other stringent tobacco control measures such as bans on smoking in all indoor areas as well as outdoor public places, bans on advertising and promotions, and increased taxation on cigarettes imported for personal use were in place. In fact, the rate of current tobacco use in Bhutan in 2014 according to a STEPwise survey was 25\% (31). To date, in line with the implementation of the World Health Organization (WHO) Framework Convention of Tobacco
Control (FCTC), which is an international binding public health treaty on tobacco control, more comprehensive tobacco control policies have been evaluated globally and have repeatedly shown to be successful in decreasing smoking rates. These policies include bans on smoking indoors with penalties for violation, bans on promotion and advertising, as well as larger pictorial warnings on all tobacco products. More in-depth evaluations of tobacco sales bans, such as those in Mecca, Medina and Bhutan, are needed to build evidence and further shed light on the effectiveness of this policy in decreasing tobacco consumption as a stand-alone policy, independent of other tobacco control policies.

The current findings showed that waterpipe and cigarette tobacco use was associated with university level, age, monthly household income, number of others living in the home and living away from parents. However, gender was associated only with cigarette smoking but not waterpipe use, indicating social acceptance of waterpipe use among women in the region (32). Gender and age were found to be associated with smoking among Saudi smokers (24). Having smoker friends and being male were the highest risk factors for tobacco use among dental students at King Saud University in Riyadh (33). A family member smoker was the main factor associated with smoking among female students in Dammam city (25). Amin et al. (16) showed in 2010 that gender, age and having relatives and friends as smokers were among the major factors associated with waterpipe smoking. In other countries in the region, gender, income, living away from parents and having relatives/friends as smokers were among the risk factors for waterpipe/cigarette smoking $(3,22,23,34,35)$. Thus, risk factors for tobacco use are shared among university students in Taibah University and other local and regional universities.

Among the limitations of the current study was that we did not examine prevalence of tobacco use among Taibaih University students in branches other than Medina main campus where tobacco sales are allowed. In addition, the study was cross-sectional; therefore, change in tobacco use over several years was not examined.

\section{Conclusion}

The current study indicates that waterpipe and cigarette smoking are common among students at Taibah University in Medina, irrespective of the ban on tobacco product sales in that area. However, the results advocate implementation of more comprehensive tobacco control measures such as smoke-free environments, increased taxation of tobacco products, bans on advertising, promotion and sponsorship, and larger pictorial health warnings in line with FCTC and WHO MPOWER measures. Future studies that compare prevalence of tobacco use in Medina and Mecca to that in other Saudi cities (where tobacco sales are not banned) are recommended to shed light on the effectiveness of such bans.

Funding: None.

Competing interests: None declared. 


\section{Consommation de tabac et utilisation de la pipe à eau chez les étudiants à l'université en Arabie saoudite : incidence de l'interdiction des ventes de tabac RÉSUMÉ}

Contexte : La consommation de tabac par pipe à eau est une forme de tabagisme qui ne cesse de s'étendre à travers le monde. En 2002, une interdiction sur les ventes de tabac a été adoptée dans les villes saoudiennes de la Mecque et Médine.

Objectifs : La présente étude avait pour but d'analyser la prévalence du tabagisme par cigarette et pipe à eau chez les étudiants de l'université Taibah, plus grand établissement universitaire de Médine dans lequel l'interdiction sur les ventes de tabac est appliquée.

Méthodes : Un questionnaire structuré a été distribué entre février et avril 2015 pour analyser la consommation de tabac chez les étudiants de l'université Taibah.

Résultats : La prévalence de l'utilisation de la pipe à eau à tout moment dans le passé était de 36,04\% contre $24,2 \%$ au moment de l'étude, alors que les chiffres associés à la consommation de cigarettes sont de $42,7 \%$ et $31,9 \%$ respectivement. Cette prévalence est semblable à celle observée lors d'études menées dans d'autres villes saoudiennes où les ventes de tabac sont autorisées. L'analyse multivariée a montré que l'utilisation de la pipe à eau était plus importante chez les étudiants de cycle supérieur, ceux dont les dépenses d'argent de poche excèdent 500 riyals saoudiens (SAR) par mois, ceux dont le foyer dispose d'un revenu mensuel compris entre SAR 5000 et 9000 et dans les foyers comptant au moins cinq personnes. En comparaison, la consommation actuelle de cigarettes était supérieure chez les plus de 22 ans, les étudiants de sexe masculin, ceux dont les dépenses d'argent de poche dépassent SAR 500/mois et ceux vivant loin de chez leurs parents.

Conclusions : Dans l'ensemble, malgré l'interdiction sur les ventes de tabac, la consommation de tabac par pipe à eau et cigarette est toujours courante parmi les étudiants de l'université Taibah à Médine (Arabie saoudite).

$$
\begin{aligned}
& \text { تعاطي التبخ والشيشة بين طلاب الجامعة، المملكة العربية السعودية: تأثير حظر مبيعات التبغ } \\
& \text { هيثم درادكه، عمر خابور، كارم الزعبي، ريا نقاش، توماس آيسنبيرج }
\end{aligned}
$$

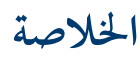

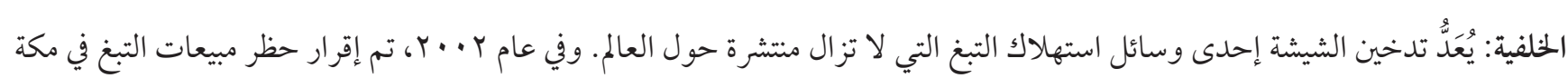

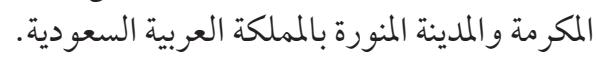

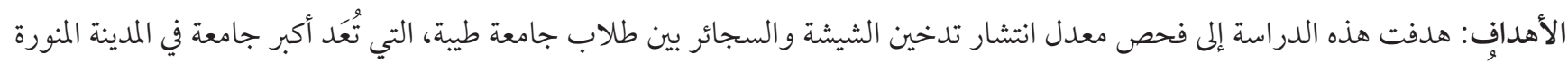

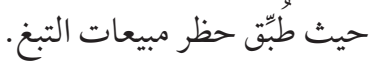

$$
\begin{aligned}
& \text { طرق البحث: استُخدم استبيان هيكلي لتحقيق أهداف الدراسة. }
\end{aligned}
$$

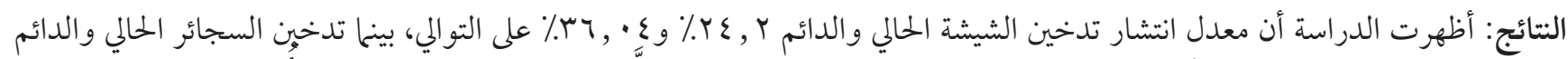

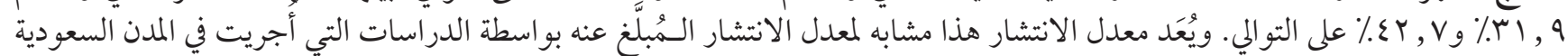

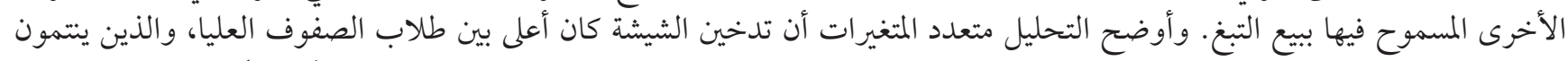

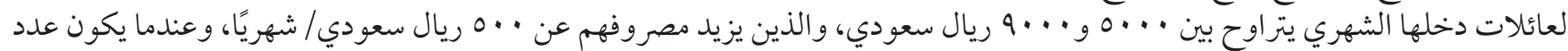

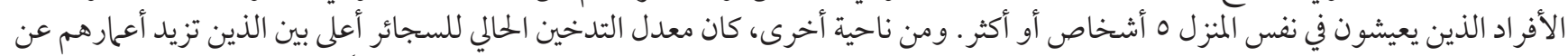

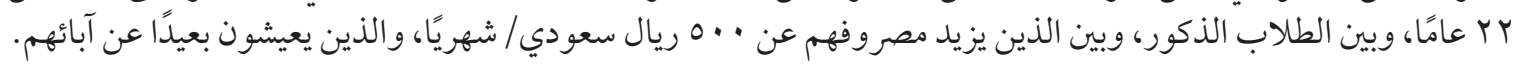

$$
\begin{aligned}
& \text { الاستنتاجات: إجمالاً، لا يز ال تدخين الشيشة والسجائر، رغم حظر مبيعات التبغ، شائعًا بين طلاب جامعة طيبة في المدينة بالمملكة العربية السعودية. }
\end{aligned}
$$

\section{References}

1. World Health Organization fact sheets. Tobacco [website]. Geneva: WHO; 2018 (http://www.who.int/en/news-room/fact-sheets/ detail/tobacco, accessed 7 February 2019).

2. Maziak W, Taleb ZB, Bahelah R, Islam F, Jaber R, Auf R, et al. The global epidemiology of waterpipe smoking. Tob Control. 2015 Mar;24 Suppl 1:i3-12. http://dx.doi.org/10.1136/tobaccocontrol-2014-051903 PMID:25298368

3. Maziak W, Fouad FM, Asfar T, Hammal F, Bachir EM, Rastam S, et al. Prevalence and characteristics of narghile smoking among university students in Syria. Int J Tuberc Lung Dis. 2004 Jul;8(7):882-9 PMID:15260281 
4. Akl EA, Ward KD, Bteddini D, Khaliel R, Alexander AC, Lotfi T, et al. The allure of the waterpipe: a narrative review of factors affecting the epidemic rise in waterpipe smoking among young persons globally. Tob Control. 2015 Mar;24 Suppl 1:i13-21. http:// dx.doi.org/10.1136/tobaccocontrol-2014-051906 PMID:25618895

5. Eissenberg T, Shihadeh A. Waterpipe tobacco and cigarette smoking: direct comparison of toxicant exposure. Am J Prev Med. 2009 Dec;37(6):518-23. http://dx.doi.org/10.1016/j.amepre.2009.07.014 PMID:19944918

6. Alomari MA, Khabour OF, Alzoubi KH, Shqair DM, Eissenberg T. Central and peripheral cardiovascular changes immediately after waterpipe smoking. Inhal Toxicol. 2014 Aug;26(10):579-87. http://dx.doi.org/10.3109/08958378.2014.936572 PMID:25144473

7. Alsatari ES, Azab M, Khabour OF, Alzoubi KH, Sadiq MF. Assessment of DNA damage using chromosomal aberrations assay in lymphocytes of waterpipe smokers. Int J Occup Med Environ Health. 2012 Jun;25(3):218-24. http://dx.doi.org/10.2478/s13382-0120027-5 PMID:22729491

8. Alzoubi KH, Khabour OF, Alharahshah EA, Alhashimi FH, Shihadeh A, Eissenberg T. The effect of waterpipe tobacco smoke exposure on learning and memory functions in the rat model. J Mol Neurosci. 2015 Oct;57(2):249-56. http://dx.doi.org/10.1007/ S12031-015-0613-7 PMID:26160697

9. Khabour OF, Alzoubi KH, Al-Sheyab N, Shihadeh A, Eissenberg T. Investigating the effects of exposure to waterpipe smoke on pregnancy outcomes using an animal model. Nicotine Tob Res. 2016 May;18(5):585-9. http://dx.doi.org/10.1093/ntr/ntv275 PMID:26681774

10. Khabour OF, Alzoubi KH, Bani-Ahmad M, Dodin A, Eissenberg T, Shihadeh A. Acute exposure to waterpipe tobacco smoke induces changes in the oxidative and inflammatory markers in mouse lung. Inhal Toxicol. 2012 Aug;24(10):667-75. http://dx.doi.org/10. 3109/08958378.2012.710918 PMID:22906173

11. Rababa'h AM, Sultan BB, Alzoubi KH, Khabour OF, Ababneh MA. Exposure to waterpipe smoke induces renal functional and oxidative biomarkers variations in mice. Inhal Toxicol. 2016 Sep;28(11):508-13. http://dx.doi.org/10.1080/08958378.2016.1210703 PMID:27477853

12. Al-Sheyab NA, Al-Fuqha RA, Kheirallah KA, Khabour OF, Alzoubi KH. Anthropometric measurements of newborns of women who smoke waterpipe during pregnancy: a comparative retrospective design. Inhal Toxicol. 2016 Nov;28(13):629-35. http://dx.doi. org/10.1080/08958378.2016.1244227 PMID:27780378

13. Ward KD, Siddiqi K, Ahluwalia JS, Alexander AC, Asfar T. Waterpipe tobacco smoking: the critical need for cessation treatment. Drug Alcohol Depend. 2015 Aug 1;153:14-21. http://dx.doi.org/10.1016/j.drugalcdep.2015.05.029 PMID:26054945

14. Saloojee Y, Chaouki N. Tobacco Free Mecca and Medina, 2007. World Health Organization, Regional Office for the Eastern Mediterranean and University of California San Francisco: Center for Tobacco Control Research and Education (https://escholarship. org/uc/item/46p7t7g8, accessed 4 February 2019).

15. [The largest area in the world where the sale of tobacco is prohibited]. Asharq Al-Awsat. 21 September, 2007 (http://archive.aawsat. com/details.asp?section=43\&article=437925\&issueno=10524\#.WB4psfl95PZ, accessed 4 February 2019) (in Arabic).

16. Amin TT, Amr MA, Zaza BO, Suleman W. Harm perception, attitudes and predictors of waterpipe (shisha) smoking among secondary school adolescents in Al-Hassa, Saudi Arabia. Asian Pac J Cancer Prev. 2010;11(2):293-301. PMID:20843104

17. Al Nohair SF. Prevalence of smoking and its related behaviors and beliefs among secondary school students in riyadh, saudi arabia. Int J Health Sci. 2011 Jan;5(1):51-7. PMID:22489230

18. Sreedharan J. RE: Water pipe (shisha) smoking among male students of medical colleges in the eastern region of Saudi Arabia. Ann Saudi Med. 2010 Jul-Aug;30(4):330. http://dx.doi.org/10.4103/0256-4947.65260 PMID:20622355

19. Mansour AY. Predictors of Smoking among Saudi Dental Students in Jeddah. Am J Health Behav. 2017 May 1;41(3):329-37. http:// dx.doi.org/10.5993/AJHB.41.3.12 PMID:28376977

20. Shah AH, ElHaddad SA. Oral hygiene behavior, smoking, and perceived oral health problems among university students. J Int Soc Prev Community Dent. 2015 Jul-Aug;5(4):327-33. http://dx.doi.org/10.4103/2231-0762.161765 PMID:26312233

21. Kingdom of Saudi Arabia Ministry of National Guard. Health affairs [website] (http://ngha.med.sa/English/MedicalCities/AlMadinah/Pages/AboutAlMadinahAlMunawwarah.aspx, accessed 4 February 2019).

22. Azab M, Khabour OF, Alkaraki AK, Eissenberg T, Alzoubi KH, Primack BA. Water pipe tobacco smoking among university students in Jordan. Nicotine Tob Res. 2010 Jun;12(6):606-12. http://dx.doi.org/10.1093/ntr/ntq055 PMID:20418383

23. Khabour OF, Alzoubi KH, Eissenberg T, Mehrotra P, Azab M, Carroll MV, et al. Waterpipe tobacco and cigarette smoking among university students in Jordan. Int J Tuberc Lung Dis. 2012 Jul;16(7):986-92. http://dx.doi.org/10.5588/ijtld.11.0764 PMID:22525279

24. Moradi-Lakeh M, El Bcheraoui C, Tuffaha M, Daoud F, Al Saeedi M, Basulaiman M, et al. Tobacco consumption in the Kingdom of Saudi Arabia, 2013: findings from a national survey. BMC Public Health. 2015 Jul 5;15(1):611. http://dx.doi.org/10.1186/s12889-0151902-3 PMID:26141062

25. Koura MR, Bahnassy AA, Al-Dossary AF. Smoking pattern among female college students in Dammam, Saudi Arabia. J Family Community Med. 2011 May;18(2):63-8. http://dx.doi.org/10.4103/2230-8229.83370 PMID:21897913

26. Awan KH, Alrshedan A, Al Kahtani M, Patil S. Waterpipe smoking among health sciences university students: Knowledge, attitude and patterns of use. Saudi Dent J. 2016 Oct;28(4):189-93. http://dx.doi.org/10.1016/j.sdentj.2016.05.001 PMID:27872550

27. Dar-Odeh N, Alnazzawi A, Shoqair N, Al-Shayyab MH, Abu-Hammad O. Waterpipe tobacco smoking among dental practitioners: prevalence and health perceptions. Tob Use Insights S40568. 2016 Sep 25;9:29-33. http://dx.doi.org/10.4137/TUI.S40568 
PMID:27695374

28. Saeed AA, Khoja TA, Khan SB. Smoking behaviour and attitudes among adult Saudi nationals in Riyadh City, Saudi Arabia. Tob Control. 1996 Autumn;5(3):215-9. http://dx.doi.org/10.1136/tc.5.3.215 PMID:9035357

29. Tobacco-free cities for smoke-free air: a case study in Mecca and Medina, WHO smoke-free city case study. Cairo: World Health Organization Regional Office for the Eastern Mediterranean.; 2011 (http://www.emro.who.int/images/stories/tfi/documents/ PUB_KOBE_TOBACCO_FREE_CITIES_SAUDI_EN.pdf, accessed 7 February 2019).

30. The International Tobacco Control Policy Evaluation Project, ITC Bhutan Project Report. Waterloo, Ontario: University of Waterloo; Cairo: World Health Organization Regional Office for the Eastern Mediterranean; 2011 (https://www.itcproject.org/files/ Report_Publications/National_Report/itcbhutanreportapr27v2oweb.pdf, accessed 4 February 2019).

31. Gurung MS, Pelzom D, Dorji T, Drukpa W, Wangdi C, Chinnakali P, et al. Current tobacco use and its associated factors among adults in a country with comprehensive ban on tobacco: findings from the nationally representative STEPS survey, Bhutan, 2014. Popul Health Metr. 2016 Aug 8;14:28. http://dx.doi.org/10.1186/s12963-016-0098-9 PMID:27507928

32. Akl EA, Jawad M, Lam WY, Co CN, Obeid R, Irani J. Motives, beliefs and attitudes towards waterpipe tobacco smoking: a systematic review. Harm Reduct J. 2013 Jul 2;10(1):12. http://dx.doi.org/10.1186/1477-7517-10-12 PMID:23816366

33. AlSwuailem AS, AlShehri MK, Al-Sadhan S. Smoking among dental students at King Saud University: consumption patterns and risk factors. Saudi Dent J. 2014 Jul;26(3):88-95. http://dx.doi.org/10.1016/j.sdentj.2014.03.003 PMID:25057228

34. El Awa F, Fouad H, El Naga RA, Emam AH, Labib S, El Naga RA, Emam AH, Labib S. Prevalence of tobacco use among adult and adolescent females in Egypt. East Mediterr Health J. 2013 Aug;19(8):749-54. http://dx.doi.org/10.26719/2013.19.08.749 PMID:24975361

35. Forden CL, Carrillo AM. Smoking and attitudes toward smoking policy at a University in Egypt. J Ethn Subst Abuse. 2016 OctDec;15(4):329-45. http://dx.doi.org/10.1080/15332640.2015.1066288 PMID:26643975 